Kohl: A Journal for Gender and Body Research

Vol. 1, No. 1 (Summer 2015)

\title{
Re-Orienting Desire from With/In Queer Arab Shame: Conceptualizing Queer Arab Subjectivities through Sexual Difference Theory in a Reading of Bareed Mista3jil
}

\author{
Sarah Hamdan
}

\begin{abstract}
:
This paper, whose title alludes to Joseph Massad's article "Re-Orienting Desire: The Gay International and the Arab World" (2002) aims at critically discussing his ideas. To do so, I mobilize Julia Kristeva and Luce Irigaray's theorizations of sexual difference. Their understandings of becoming-subject will be put in conversation with a close reading of shame in Bareed Mista3jil: True Stories, as guided by Dina Georgis' analysis, in order to engage with the hybrid and affective articulations of Arab (homo)sexualities.
\end{abstract}




\section{Introduction}

"Lesbian is such an ugly word to me. It makes me cringe- especially the French version that is more often used in Lebanon 'Lesbienne' (with an elongated 'ieeeen'). Ugh. Even worse was the word 'dyke.' But it's still all good compared to 'sou7aqiyyeh.' That one really makes me want to vomit... I find it intriguing how people form certain images to go with words, how they give absolute meanings to words. When they say the word 'lesbian,' it represents a single image in their heads. They have no idea what different and diverse people the word 'lesbian' can represent."

Anonymous, Bareed Mista3jil: True Stories (2009), from El-Ariss (2013, p. 7).

Bareed Mista3ji: True Stories (2009) is a collection of autobiographical stories by Lebanese queer women and transgendered from the Beirut-based queer group Meem, in which sexuality is talked about in relation to identity, family struggle, socio-political dimensions as well as religion and class. The stories in Bareed will be analyzed throughout this paper. In the quote above, the author strongly interrogates the term "lesbian," shifting between three languages, and identifying different sites where sexuality is in a constant state of negotiation (El-Ariss, 2013, p.114). Fluctuating between multiple intonations, affects, as well connotations, the author challenges the monolithic identity of the term "lesbian," multiplying its complexity by referring to different gender attributes, sexual identities, cultures, and sounds. She also seems to be negotiating her experiences of shaming in a process of relationality that is different from post-Stonewall politics of queer pride/coming-out (which focuses on overcoming shame), and which implies hybridity. In this sense, the word "lesbian" has many layers triggering diverse reactions and seems to be irreducible to the binary opposition between Western and Arab sexualities, since it appears as constantly negotiated. This process of negotiation, I argue, could be captured by rhizomatically investigating bodily affects and hybridities rather than engaging in a dialectical analysis of Western hegemony (resistance/complicity model).

These complex and affective articulations of Arab (homo)sexualities, ${ }^{1}$ I claim, do not seem to have space in the current debates on Arab (homo)sexualities, which exclusively rely on the critique of Western colonial discourse. Affect, which possesses a potential for new sites of transformation and embodiment, has been underdeveloped in theories of sexuality (El-Ariss, 2013, p. 7; Grosz, 2005, p.1, Ettinger, 2006, p.219). But before expounding on the problems of exclusively discursive theoretical frameworks and in the aim of advancing such a critical engagement, I will begin by introducing Joseph Massad's Desiring Arabs (2007), which is among recent scholarship on the topic of Arab (homo)sexualities.

\footnotetext{
${ }^{1}$ I intend to use the terms "queer" and "(homo)sexual"/"(homo)sexualities" interchangeably, although I am aware of the larger theoretical debates in gender and queer studies around these notions, but I will not engage in this discussion due to time and space constraints. And the choice of brackets on "homo" means "sexual and homosexual"/"sexualities and homosexualities."
} 
In his refinement of Foucault's theorizations of sexuality, Massad indicates that the colonial deployment of sexuality as a concept, was mainly internalized within the Arab intelligentsia, and imposed through an ontological frame, not only through an epistemological one (Puar, 2011). This paper will acknowledge his critique of Western hegemony's discursive construction of Arab (homo)sexuality, which he called the Gay International. However, it will argue that his approach contains blind spots and will search for possibilities to articulate Arab (homo)sexualities outside of the frames of complicity with Western hegemony. To engage with this endeavor, and since the notion of an Arab (homo)sexuality is closely linked to theorizations of subject-making, I chose to intervene with feminist theories of sexual difference, in the works of Julia Kristeva and Lucy Irigaray, in order to theorize and imagine Arab queer subjectivities. ${ }^{2}$

Hence my research question: In attempting to decolonize orientalist Western accounts of Arab (homo)sexualities, how do sexual difference theorizations of subjectivity in the works of Kristeva and Irigaray, when put in conversation with an affective reading of queer shame in Bareed, qualify Joseph Massad's thesis?

After investigating Massad's thesis, I will engage his historical and epistemological models of sexuality with feminist theorizations of (sexual) difference. I will investigate Kristeva's concept of revolt, which is the interrogation of the self, as well a movement of discontent, and a retrospective return. And I will attend to the philosophical antifoundationalism of Irigaray's sexual difference and her insistence in undoing modern monosexual subjectivity while focusing on her concept of hommosexuality, and her sexual ethics. I argue that Kristeva and Irigaray's formulations of sexual difference have the potential to theorize reconfigurations for Arab (homo)sexualities. This engagement will be complemented by the close reading of the book Bareed Mista3jil: True Stories (2009), by Dina Georgis (2013), which scrutinized the affects of shame underlying the stories, and which could be considered as a generative force for the process of Arab queer becoming. These narratives capture Arab queer subjectivities that are hybrid, incomplete, in a process of becoming, and yet that are constantly negotiated and cultivated (Georgis, 2013, p.234).

\footnotetext{
2 I use the notion of Arab queer subjectivities rather than Arab queer identities, because of the limitations of identitarian models and identity politics. Hence, my usage of the notion of subjectivity is informed by an affective and antiidentitarian approach in poststructuralist feminist scholarship, which views the subject as non-linear, non-unitary, nonuniversal, non-phallocentric and nomadic (Braidotti, 2006; Puar, 2007). Affective analyses approach queer subjectivities that are unknown and in the process of becoming, that are neither visible nor transcendent, as assemblages spatially and temporally contingent, rather than identities (Puar, 2007). The poststructuralist approach is informed by a Foucauldian framework of subject formation through discourse along modes of power/knowledge. For instance, the subject is constituted performatively through the reiteration of norms along a doing/undoing conceptualized through psychoanalysis (Butler, 1997). Moreover, Mahmood (2005) expanded on Butler's understanding of subjectivity by focusing on the constitutive aspect of norms to the subject's valorized interiority. The subject is also understood as "a process of negotiation between material and semiotic conditions that affect one's embodied, situated self” (Braidotti, 2002, p.75).
} 


\section{Joseph Massad's Critique of Hegemonic Sexuality}

In Desiring Arabs (2007), Joseph Massad engaged in a scholarly research about the genealogy of Arab sexuality, by studying the intellectual history of the modern Arab world as a counterpart to colonialist and orientalist discourses. Massad attempts to qualify Foucault's concept of sexuality through a post-colonial approach. Foucault mainly argues that the modern Western society of the nineteenth century witnessed the development of the prison, the legal and political systems, and the clinic, which sought to categorize and treat people. In this context of modernity, the experience of sexuality (and the category of homosexuality) was constructed discursively in connection to modes of knowledge, power, normativity, and culturally coded subjectivities. Massad concurs to this analysis.

However, according to Massad, Foucault failed to insert into his analysis the relationship of modernity to colonialism. In this regard, he is not arguing that Foucault was not punctilious in historicizing the way with which the concept of sexuality was applied to the colonized. Massad rather argues that this concept is itself a product of the colonial experience (Massad, 2007, p.7).

Massad was influenced by Edward Said's work Orientalism (1978), in which Western scholarship is examined in its imperialist, ahistorical, essentialist and orientalist legacies along the Foucauldian framework of power/knowledge. Said particularly focused on European knowledge production, which was characterized by the binary construction of the West/Orient as a counterpart of the SelflOther. Said called this discourse Orientalism, which he defined as a "style of thought based upon ontological and epistemological distinction made between 'the Orient' and (most of the time) 'the Occident'" (Said, 1978, p.10).

Massad hence claims to be intervening in Said's post-colonial framework through the Foucauldian conceptual tools of sexuality/subjectivity formation. I will later assess whether Massad's contribution is indeed meticulous to Said's critique of Orientalism. To go further, and before shifting the focus to Massad's claims about the Gay International, it is relevant to briefly examine how Massad built his arguments.

Massad examined the works of Arab intellectuals since the 19th century and highlighted their influence by Orientalist scholarship, which considered that Arab tradition (as well as Islam) had undergone a period of "degradation" and "primitiveness" during the Ottoman rule. This period of "moral decline" was one of the main mobilizing factors for the rise of Arab nationalism, and Nahda (Arab renaissance) (Massad, 2007, pp.8-9). In this sense, Western hegemonic ideas and identities have shaped the writings of Arab intellectuals, as well as the ways in which sexuality was evocated in Western identity politics and human rights groups in the 1980s. These developments have had an influence on responses from Arab nationalism, and Islamic ones especially. Henceforth, conceptions of sexual desires and practices in contemporary Arab society have been constructed in relation to these colonialist, orientalist and nationalist epistemologies (Ibid., pp.48-49). The production of Arab (homo)sexuality was also closely linked to modernity processes. I focus in this paper on 
a particular critique advanced by Massad, which is the universalization of Western sexual identities through the Western gay rights discourse, which he called the Gay International.

One of Massad's arguments follows his critique of orientalist discourse on sexuality, and the epistemology with which it is constructed. He highlights the way in which Western gay rights organizations, activism, and scholarship influence the internalization of this epistemology in the Arab world through "incitement to discourse." He points out that the universalization of the category of homosexuality by international human rights groups should be seen as an "epistemic, ethical and political violence" (Ibid., p.41). In other words, this universalization of the categories of heterosexuality and homosexuality (by the Gay International in particular) is a form of Western sexual imperialism. It imposes an ontological binary construction of sexuality on Arab subjectivities that did not traditionally have, in their authentic culture, similar sexuality categories (and along with it, homophobia, which also did not exist in Arab culture).

While Massad's critique of sexual imperialism and of Orientalist scholarship on Arab (homo)sexuality is legitimate, it nevertheless seems to be lacking a more-nuanced approach to Arab queer subjectivities. His theory has been accused by various Arab scholars and activists of being essentialist, of reproducing a certain thesis of the "clash of civilization" (Taha, 2013), and of denying Arab homosexuals of subjectivity, by calling them "victims of orientalist fantasies" (Amer, 2010, p.652). What is most problematic is that Massad is considered to be asserting a form of cultural authenticity to Arab sexuality that is homogenous and static, instead of accounting for its complexities, hybridity, and its creative postcolonial feature of negotiating and reinventing itself3 (Abu-Odeh, March 25, 2013; Anderson, 2010; Georgis, 2013; Makarem, December 14, 2009).

So how can we move beyond Massad's binaries and cultural authenticities, and rather envision affirmative forms of difference for articulations of Arab queer subjectivities? In what follows, the tools for articulating

\footnotetext{
${ }^{3}$ Makarem (December 14, 2009) and Anderson (2010) contented that Massad's accusation to the Lebanese LGBTG organization Helem, of being an agent of Western imperialism, is unfounded. They argued that Helem and Meem's (Lebanese queer group) activism is particularly anti-imperialist, anti-Zionist, critical of the agenda of the 'Gay International', and postcolonial because it aims to work from within the (colonialist) power structures to fight both colonialism and homosexual oppression. Moreover, Makarem emphasized the paradoxes and the resulting risks of Massad's adherence to the notion of 'authentic national sexual identity', and how it resonates with the 'homophobic' opinions of oppressive states and religious leaders. Moreover, Abu-Odeh (March 25, 2013) criticized Massad's thesis, and in particular his contradictory understanding of the workings of power as being textual/Foucauldian (residing in language) and at the same time realist/Marxist/structuralist (residing in social relations). This theoretical understanding of same sex acts results in incapacity to interrogate techniques of power (Foucault) or to search for social contradiction (Marx) because Arab cultural difference just is. Hence, Abu-Odeh points to the problematic (paranoid) conclusion of safeguarding an authentic cultural Arab same-sex practice.
} 
queer Arab becomings ${ }^{4}$ will be looked at more closely, by putting feminist philosophy of sexual difference ${ }^{5}$ in conversation with an affective ${ }^{6}$ reading of the narratives in Bareed.

\section{Sexual Difference Theory and the Force of Queer Shame in Bareed Mista3jil}

\section{Thinking Queer Arab Subjectivities as Revolt through the Force of Queer Shame}

In Revolt, She Said (2002), Kristeva articulates the concept of revolt in contrast to the idea of a political revolution, which is entrenched in the confrontation and transgression of normative modalities. Revolt is rather engrained in "the self-questioning and [the] questioning [of] tradition as well, sexual differences, projects for life and death, new modalities of civil society and so on" (Ibid., p.85).

Revolt is also a "very deep movement of discontent, anxiety and anguish [and] to say that revolt is only politics is a betrayal to this vast movement" (Ibid., p.99). Etymologically, the word revolt means to discover, to open, -which would signify that Arab (homo)sexualities as a category should open itself and break from the colonial imperialism it carries- but also to turn and return, (Ibid., p.100). Following this line of thought, Kristeva's revolt would read the quest for a figuration of Arab (homo)sexualities also as a search, a retrospective return, a rehabilitation of memories of trauma, and a performance of transformative creativity, which arises through nothingness and through the process of questioning (Ibid, pp.100-101). A re-orienting of desire seen through the perspective of a revolt would precisely be this process of interrogation and this engagement with a retrospective return. This should not be confounded with a historical return to old authentic forms of Arab homosexual practices, and for that matter, neither with an act of resistance against Western constructs of

\footnotetext{
${ }^{4}$ My take on the notion of becoming is inspired by Braidotti's reading of Deleuze's work, which wants to reverse the dialectics of negativity. As such, Deleuze's thought opposes the philosophies of Hegel, Husserl and Heidegger, and is based on the works of the empiricists Spinoza, Nietzsche and Bergson. Becoming is "the affirmation of the positivity of difference, meant as a multiple and constant process of transformation, [in which] both teleological order and fixed identities are relinquished in favor of a flux of multiple becoming" (Braidotti, 2011, p.246). The in-between spaces are what matters in this process of unfolding of positive difference (Braidotti, 2002, p.72). Nevertheless, there are tensions between Deleuzian theories of becoming-subject and feminist theories of sexual difference such as Irigaray's (Ibid., p.75).

${ }^{5}$ My understanding of feminist philosophy of sexual difference is informed by the ethico-onto-epistemological as well as political dimensions of the works of scholars like Braidotti (2002, 2006, 2011), Ettinger (2006), Grosz (2005), Huffer (2011), Irigaray (2000), Kristeva (2002), and Thiele (2014).

${ }^{6}$ I understand affects from Deleuze/Spinoza as the capacity of the body to be affected, to enter relations, as conatus (Braidotti, 2002). Affects de-essentialize the body and sexed identities; subjectivity is a bodily and affective entity in a process of intersecting forces and spaciotemporal variables (Braidotti, 2011). Crucially, "affects arise in the midst of inbetween-ness: in the capacities to act and be acted upon. Affect is an impingement or extrusion of a momentary or sometimes more sustained state of relation as well as the passage (and the duration of a passage) of forces or intensities" (Gregg \& Seigworth, 2010, p.1).
} 
homosexuality categories. In order to illustrate how this concept of revolt could contribute to postcolonial configurations of Arab queer subjectivities ${ }^{7}$, a reading of queer shame in Bareed Mista3jil is useful.

Georgis indicates that the stories in Bareed reveal a community that seems to be in the process of creatively negotiating the painful experiences of shaming and marginalization from society and family (2013, p.235). The authors- although not entirely- are distancing themselves from the post-Stonewall political strategies of queer pride, which focused on overcoming shame. They rather seem to invent their community through and not against shame. They refuse to abide to the binary choice of rejecting traditional, un-modern shame (by opposing tradition and their family) and embracing modern, sexual freedom (by coming out according to pride logic) (lbid., p.235). Notably, Sedgwick has theorized that shame always occurs in relation to others and that it activates our concerns about our deepest investments in relationality (lbid., p.234). Moreover, shame has immediate bodily effects; it generates reflection and invention.

Thinking through Massad's argument, his understanding of difference in relation to Arab subjectivities entails a traditional/authentic form of Arab same-sex sexual practices that could have remained pure from colonial interference. This notion of cultural authenticity considers tradition as static and does not account for the complexities of Arab postcolonial subjectivities (Ibid., p.237). As Paul Gilroy theorized, postcolonial subjectivities are characterized by hybridity and by the feature of negotiating worlds. Hence, in order to capture this process of negotiation that same-sex Arab sexualities are living, attention should be given to their affects and their hybridity rather than emphasizing their resistance/complicity with Western hegemony, which characterizes Massad's endeavor (Ibid., p.237).

That being said, in the close-reading of Bareed, Arab (homo)sexualities in the narratives cannot be categorized along the binaries of modern/traditional, or Western/non-Western. They are rather revolting, and in the process of being constantly negotiated.

The example of the use of Arabish is helpful to unpack that last claim. Arabish is the transliteration system used to write Arabic in Latin letters and numbers, which is usually present on online social networks, but was also employed in book Bareed. The authors express the difficulties in framing their sexualities using classical Arabic expressions and preferred English or French. They explain it by the wider prominence of these languages on the Internet and in papers written about LGBT issues and gender/sexuality, and the influence of Western LGBT discourse, as well as the earlier limited support to Arabic characters/keyboards in online communication (Georgis, 2013, p.238). Arabish should be considered a hybrid form of communication. This linguistic hybridity allows the authors of Bareed to be more comfortable to write (in English with Arabish),

\footnotetext{
7 The notion of 'tacit subjectivity' coined by Decena (2008) could also be useful in this analysis to criticize the privileging of the process of 'coming out of the closet' (as well as a rigid conception of visibility in the public sphere). Tacit subjectivity draws a distinction between verbalizing and living non-normative sexuality. As such, tacit subjectivities live non-normative sexuality without verbalizing it, and by that, they challenge the dichotomy of visibility/invisibility and inhabit in-between spaces in relation to the metaphor of the closet.
} 
since they do not easily recognize queer jargon translated to classical Arabic, and this would also allow them to use Lebanese Arabic dialect (usually not used in formal writing). Georgis argues that Arabish reflects the real and symbolic lived realities of contemporary queer Arab subjectivities, which do not seem to be interested in authentic same-sex sexualities (2013, p.239). As such, it becomes clear that, even though they are certainly influenced by Western onto-epistemological knowledges, the authors narrativize the revolt experiences of living in Lebanon and how they struggle with the imposition of norms, with the socio-political problems of the region, the traumas of war, as well as the legacies of French colonialism (Ibid.). The same analysis applies to the example of the word "lesbian" and its meanings, which was discussed earlier in the introductory quote of the paper. Moreover, they are vocal about how important and relieving it is for them to find out that there are other queers in the non-Western Arab world that share their desires and struggles. This example complicates Massad's thesis, since his defense of authentic same-sex sexualities does not seem to conjugate with the revolt and the linguistic hybridity of Arab queer subjectivities in Bareed.

In this sense, the endeavor of Bareed's authors, by their use of Arabish, would be distancing itself from the understanding of revolt as a political revolution that seeks freedom within an equality/sameness discourse, because it would result in a dogmatism and totalitarianism (Kristeva, 2002, p.81) read as the Gay International. Moreover, the philosophical meaning of revolt as "the idea that being is within us" (Ibid., p.100) would mean that the retrospective return, anamnesis, and memory as a permanent doubting and questioning are the means with which a "truth" about a hybrid Arab (homo)sexuality could be acquired. It becomes evident given this formulation, that revolt and linguistic hybridity would be completely inconceivable if the debate about Arab (homo)sexualities were to be restricted exclusively within the confines of Western hegemony and the critique of modernity discourse (El-Ariss, 2013, p.143).

\section{Lucy Irigaray's Theory of Difference}

\subsection{Thinking Queer Shame through Theorizations of Subjectivity}

The endeavor to think through the question of sexual difference must attend to Luce Irigaray's canonical theorizations of subjectivity. Irigaray's feminist philosophy aims to rethink sexuality in the context of social, political and also epistemological structures of exclusion (Grosz, 2005, p.178; Huffer, 2014, p.523), which she calls the economy of the same.

Moreover, Irigaray's project of sexual difference, which affirms the existence and the potentials of two sexes, seeks to acknowledge the failure of the past to deliver a space and time for women's subjectivity, since they have been excluded along all forms of practices and knowledges. Given this exclusion, sexual difference theory aims for a future in which different ontologies and epistemologies are provided, in order to enable subjectivity to be conceptualized in different figurations (Grosz, 2005, p.173). Irigaray articulates an understanding of the subject as a becoming rather than a being, which seeks to move beyond the unitary 
and phallic subject and beyond the binary of the sexes that we know in the present and which have existed in the past as preexisting entities (Ibid., p.174). Therefore, a crucial aspect of sexual difference is the claim that differences between the sexes, as Irigaray argues, have never taken place. In this sense, when attending to the notion of differentiated Arab (homo)sexualities, I do not draw on currently existing/authentic/real forms of (homo)sexualized subjectivities in the Arab world, and the associated resistant "homophobic" ones, as Massad does. I am rather alluding to forms of subjectivities that would come about through the transformation of current imperialist ontologies and epistemologies that have excluded the colonized from sexual subjectivity.

Referring this back to the discussion on Bareed, it seems that Irigaray's understanding of the transformations of Western onto-epistemologies could be grasped in Georgis's reading of Bareed. This reading discerns the emotional and affective registers of the narratives, at the painful site of shame in particular. Crucially, these registers entail the potential for postulating social (and political) transformative processes that are not captured by discursive/ideological analyses (as in Massad's thesis), and that do not reiterate the hegemonic epistemology of queer pride.

The suffering endured by the authors (both collective and individual), coupled with their difficulties in naming their affects of relationships and their precarity, reflects their lived realities and also a process of building a new community (Georgis, 2013, p.239). This project of difference, of creating a queer Arab becoming, is what is theorized by Irigaray's and Kristeva's project of sexual difference.

Furthermore, stories are affective strategies for digesting and negotiating difficult experiences, for imagining safety, resisting threats, and constructing the terms of community. Hence, they should be considered valuable resources for understanding postcolonial epistemologies and capturing, in a straightforward manner, those complex and indeterminate subjectivities that are full of subtle meanings (Georgis, 2013, pp.239-240).

Notably, queer pride should be seen as merely an epistemological narrative of Western subjectivities, since it emerged in the specific history of the post-Stonewall riots. And crucially, the discursive logic of queer pride constructed itself in function of the defeat of shame (Georgis, 2013, pp.240-241). In contrast, queer Arab subjectivities, while certainly being implicated in the discourse of Western queer pride, seem to relate to shame differently. The authors of Bareed do not narrate their need to defeat shame and its causes (family, society, tradition, etc.) to the same extent as their survival of it (lbid., p.242).

Sedgwick understood shame as holding the potential for cultural production, because the extreme vulnerability evoked by the gaze of the other cannot be easily disavowed (Ibid., p.242). Georgis read the narratives, in their articulation of shame, as both a literal and imaginative resource for the formation of hybrid queer Arab subjectivities. I see Bareed's stories through the lenses of Irigaray and Kristeva as a form of 
ecriture feminine ${ }^{8}$, using and imagining the Arab queer body (similarly to using the feminine body) as well as its shame to write and produce knowledge to subvert imperialist knowledge about homosexuality.

Furthermore, unlike Western LGBT groups, Meem's strategies seem to be not interested in public visibility or gay rights, but rather focus on creating a support group, on blogging, and on contributing to feminist activism in Lebanon (Ibid., p.242). Meem members consider themselves ambiguously visible and situate themselves away from the Western framework of visibility and also away from the binary of closet/coming out or visibility/invisibility (Lynn, December 16, 2010).

It is important to emphasize that this approach to reading shame is not essentialist. There is no fixed understanding of Arab shame, since the subject of shaming changes and social moral codes are not static in cultures (Georgis, 2013, p.243). However, and given this formulation of shame, it seems relevant to point out that the fear of shame is an emotional reality for most Arabs (at least for the authors of Bareed), since they live in contemporary societies where family ties and sectarian/religious identity are highly valued and are connected to economic as well as emotional survival (Georgis, 2013, pp. 243-244). Therefore, the attachment to cultural values such as family bonds or sect/religion should not be read as traditional as much as material and affective.

Thinking queer shame through Irigaray, the methodological endeavor would focus on how to advance new theoretical frameworks for thinking differently as both woman and man, (and as colonized queer Arab and Western Gay colonizer). It would also focus on how to make space for issues and concepts that have not had their time before (Grosz, 2005, p.175). Following this line of thought, subverting the universal and neutral model of (imperialist) sexuality is a task of producing future situated ${ }^{9}$ and subjugated knowledges. And this task of bringing Arab queer subjectivities into existence, which was captured in Bareed's reading, should be done without speculating in an essentialist manner what this difference might consist of.

In what follows, Irigaray's notion of hommosexuality and her sexual ethics will be looked at, by envisioning through them an engagement to re-orienting Arab desire in the stories of Bareed.

\footnotetext{
8 The term écriture feminine was coined by Helene Cixous in The Laugh of the Medusa (1975), and has been used by various French feminist theorists such as Julia Kristeva, Lucy Irigaray and Bracha Ettinger to advocate feminine difference in language and subverting phallogocentric writing through the using of the body.

${ }_{9}$ The notion of situated knowledges, advanced by Donna Haraway (1988), is a feminist critique to disembodied and un-situated (dominant) epistemological methodologies. Haraway argues that in order to reach objectivity and selfreflexivity, the researcher must privilege the partial perspectives of the marginalized. I understand Arab homosexual knowledges as situated knowledges capable of subverting the dominant and un-situated epistemological frameworks of the Gay International.
} 


\subsection{Hommosexuality as the Gay International}

Irigaray rejects the model of "Hommosexual" (with the double "m" referring to homme, the French word for man), as representing monosexuality (or heteronormativity) present in the sexual economy of the same, which she is trying to rework (Huffer, 2011, p.525). Elizabeth Grosz argues in her reading of Irigaray that:

"only when women take (up) a space and a time that are capable of mapping their unique morphologies, desires, and discourses can there be an encounter between, or touching of, the two sexes. Until then, we exist within a hom(m)osexuality that regards women only as objects, not partners" (Ibid, p.526).

In this formulation, the Hommosexual as such would be the Gay international, which indicates the need for a reconsideration of this Universalist and imperialist model of sameness, in order strategically reclaim and create at least two sexual positions, an Arab (homo)sexuality and Western one.

\subsection{The force of queer shame in conjugation with sexual ethics}

In reading Irigaray's critique of the monosubjective and monosexual tradition of sameness, the Foucauldian lens of sexual ethics, which differs from the problematic morality-based approaches, must be delineated.

Morality is what historically constructed the sexual subject from a Foucauldian lens. However, ethics is a reflection that engages with the Socratic question "how should one live?" and hence would articulate "a selfundoing practice of freedom," a "desubjectivating ethics" (Huffer, 2011, p.520). To elucidate, according to Huffer, Foucault's account of ethics is rooted in the relationality of the subject to others, and in the constant interrogation of the subject; "the ethical subject is historically linked to the emergence and disappearance of others" (2011, p.520). Hence, she suggests that Irigaray offers a sexual ethics that hinges on the idea of a transformation, that alters the morality-based ethics of sexual subjectivity from within (Ibid., p.532). To elucidate, morality-based ethics is problematic, because it is embedded in the (imperialist and heterosexist) construction of modern sexual subjectivity. Simply shattering and deconstructing the subject all together which would shatter morality along with it- could be seen as immoral, because it does not acknowledge the harm resulting from the constitutive exclusion of the other. (Ibid.). In this sense, the Arab queer Other, who is already excluded from the moral project of an unsituated, universalist, and colonialist sexuality, could only desubjugate their knowledge from inside the episteme. Irigaray's endeavor is understood, in this sense, to be a quest for a non-essentialist ontology -which contradicts what many queer theory and poststructuralist scholars have argued (lbid., p.535). And I contend, that it is, hence, a historically situated attempt to ethically decolonize internalized/discursive and non-internalized Western notions of sexuality from within the episteme of colonialism, which would challenge the binary of West/Arab subjectivities. 
In order to clarify how queer Arab subjectivities could desubjugate their knowledges from inside the episteme (from with/in, according to Irigaray's ontology) through using the force of queer shame, the narratives in Bareed will be analysed.

In one of Bareed's stories about family and shame during teenage, titled "Becoming," the author narrates how when she naively approached her Bible teacher, telling him that she is struggling with her homosexuality, her public shaming happened at school. Her teachers at school shamed her for sexual deviance, and tore her hopes for her plan to become a Christian missionary. Her angry mother locked her in her room for twelve days and socked her body in the bathtub to clean it from immoral desires (Georgis, 2013, p.244). But luckily, when she was allowed to go back to school, her friends protested her ostracization and supported her. And she later reveals that she subsequently founded Meem, partly, because she was inspired politically by such gestures of solidarity. In this story, shame was a resource to negotiate her place in society and to become aware of her vulnerability. Shame should be read here as generative, since it actuates the imaginative force for reconstructing the axes of relationality and building a community, either by reinvesting in them or by searching for collective narratives (Georgis, 2013, p.244) and creating them from with/in. As she stated: "that little tomboy who wanted to be a missionary is now an activist for social justice... I grew up to be exactly what I wanted to be" (quoted in Georgis, 2013, p.245). Therefore, what is being evaded is not the feeling of shame, but rather the consequences of public shaming, as well as the possibility of family expulsion and repression of community.

Moreover, Georgis mentions the story "When You Burn," in which the author explains that she doesn't want to come out to her family because her mother has already suffered from poverty and from many losses in her life. Another example of the importance of family belonging features is in the story "This Land is Not my Land" where the author asserts:

To me, being queer is not only about loving women, but also about being aware of my family and how they are feeling... My world revolves around the well-being of my mother, my father and my siblings... They have done so much for me that I can't just say "yalla, bye" to them (quoted in Georgis, 2013, p.247).

As such, it seems evident that for the queer Arab authors of Bareed, queer becoming is being negotiated, not in opposition to family ties and cultural/societal values through coming out, but rather in transformative and affective responses of reparation (Ibid.), located with/in the morality-based ethics of sexual subjectivity.

And lastly, in "My Hijab and I," the author who describes herself as a tomboy dyke, narrates her ambivalent relationship with the hijab, which she esteemed earlier in her life but then came to dislike after her exposure to Western media (Georgis, 2013, p.247). She explains how she was faced with even more difficulties after moving to Beirut and confronting stigmatization from the lesbian community because of her hijab. At the end, she says that she wants to keep her hijab because she sees it as a part of herself, and because it's a way to 
protect herself from being objectified by other lesbians, and also because she doesn't want to cause problems with her family (lbid, p.248). Hence, being a dyke in hijab could not be theorized along the binaries of traditional/modern but rather in the in-between-ness that could come about in the project of sexual difference, which aims to dismantle the monosubjective economy of the Same, and re-orient desire from with/in.

\section{Conclusion}

Through engaging a conversation between Massad and sexual difference theorists, this paper attempted to think of an ethico-onto-epistemological account of Arab queer subjectivities that are always in the process of becoming. Ultimately, an approach which understands Arab (homo)sexualities as fixed and homogenous rather hybrid, and that views Arab tradition exclusively as a site of resistance to Western hegemonic sexuality, would imply an "impossible return to something that is always already imagined, reconstituted or reconstructed" (El-Ariss, 2013, p.118). Such an approach neglects the affective and embodied dimensions of Arab subjectivities manifested in narrative writings, which are modules of contemporary Arab cultural production, as well as vehicles of political change (El-Ariss, 2013).

Notably, Georgis's reading of Bareed demonstrated how affects of queer Arab shame animate meaning for subjectivities that are lived in process. The authors of Bareed feel the need to perpetually search for and even imagine zones that are, simultaneously, not known in advance and predictably anticipated. The complexities of those subjectivities are located in the affective task of resisting colonial legacies, being influenced by gay imperialist epistemologies, and in negotiating their nationalist realities of moral shaming.

Furthermore, in order to elucidate how the project of sexual difference could be useful for unsettling the modern premises of sexual imperialism, the simultaneously ethical and ontological dimensions of these theories were discussed. At the same time, the feminist theory of difference was put in conversation with Georgis's affective reading of the narratives in Bareed, while focusing on the generative force of queer shame, in the aim of advancing hybrid figurations of queer Arab becoming.

Revisiting our discussion of Irigaray, sexual difference is the possibility to derange the ontological thesis shaping the divide of West/East, Arab tradition/Western Gay International, by rethinking modes of relationality with the other and the modes of becoming within a politics of difference. More precisely, since ontology is traditionally perceived as the sense of Being as "given," Irigaray posits it as being incapable of escaping the force of differentiation. Hence, instead of mistakenly positing sexual difference as a description of "what is" which would be the essentialist approach to ontology (depicted by Massad's defense of cultural authenticity) - she would argue for conceptualizing sexual difference as an ethical project, in which ontology itself is dynamically becoming transformed within this divide (Thiele, 2014, p.13). Given this formulation of an ontology of becoming, and in an attempt to conjugate queer Arab subjectivities, it becomes clear that emphasizing the difference does not entail describing the being of difference because it presupposes what 
| 67 difference is. And this is, indeed, what I wanted to problematize in Massad's insistence on discursive formations, and his disregard of affective and embodied sites of conceptualizing Arab subjectivities. Once our ontological understanding of difference shifts from a "what is" to a "becoming-different," the ethical dimension becomes evident:

difference is the force constituting everything and so it matters at every turn and every moment 'how' and 'what for' our engagement with the world is, and how we account for the effects of our differential becomings (lbid., p.14).

And at last, Irigaray's endeavor seeks to create space for non-phallogocentric genealogies, and, comparably to Kristeva's revolt, to advocate a vision for a process of re-inscribing meanings to subjectivities, and of reworking the system of signification. Her search for new ethics, when put in dialogue with Massad's critique of hegemonic sexuality, shifts the focus to new sites of embodiment, such as affective registers of narrative writing which generate queer Arab becoming. 


\section{References}

Abu-Odeh, L. (March 25, 2013). "That Thing that You Do: Comment on Joseph Massad's "Empire of Sexuality." Al-Akhbar Newspaper. Retrieved May 2, 2015, from http:/lenglish.alakhbar.com/node/15350

Amer, S. (2010). "Joseph Massad and the Alleged Violence of Human Rights." GLQ: A Journal of Lesbian and Gay Studies, 16(4), 649-653.

Anderson, J. (2010). Crossing Swords LGBTIQ NGOs in Lebanon, Joseph Massad's Critique, and Postcolonialism. (MA Thesis). American University of Beirut.

Butler, J. (1993) Bodies That Matter: On the Discursive Limits of Sex, New York/London: Routledge.

Braidotti, R. (2011). Nomadic Subjects: Embodiment and Sexual Difference in Contemporary Feminist Theory. Columbia University Press.

Braidotti, R. (2006). Transpositions: On Nomadic Ethics. Polity Press.

Braidotti, R. (2002). Metamorphoses: Towards a Materialist Theory of Becoming. Polity Press.

Decena, C. U. (2008). Tacit Subjects. GLQ: A Journal of Lesbian and Gay Studies, 14(2-3), 339-359.

El-Ariss, T. (2013). Trials of Arab Modernity: Literary Affects and the New Political. Fordham Univ Press.

Ettinger, B. (2006). "Matrixial Trans-subjectivity." Theory, Culture \& Society 23/2-3, 218- 222.

Georgis, D. (2013). "Thinking Past Pride: Queer Arab Shame in Bareed Mista3jil." International Journal of Middle East Studies, 45(02), 233-251.

Gregg, M., \& Seigworth, G. J. (Eds.). (2010). The Affect Theory Reader. Duke University Press.

Grosz, E. (2005). "The Force of Sexual Difference." Time Travels. Feminism, Nature, Power, Durham/London: Duke University, 185-195.

Haraway, D. (1988). "Situated Knowledges: The Science Question in Feminism and the Privilege of Partial Perspective." Feminist studies, 575-599.

Huffer, L. (2011). "Are the Lips a Grave?" GLQ: A Journal of Lesbian and Gay Studies, 17(4), 517-542.

Irigaray, L (2000). Democracy Begins Between Two. London: The Athlone Press, 30-40, 121-156.

Kristeva, J. (2002). Revolt, She Said. Semiotexte Foreign Agents Series. New York: Columbia, pp. 67-110.

Lynn (December 16, 2010). "Framing Visibility: Coming Out and the International LGBT Spectrum of Progress." Sexgenderbody. Retrieved May 2, 2015, from http://sexgenderbody.com/content/framingvisibility-coming-out-and-international-lgbt-spectrum-progress\#ixzz3Z190nv9A

Massad, J. (2008). Desiring Arabs. University of Chicago Press.

Makarem, G. (December 14, 2009). "We Are Not Agents of the West: Ghassan Makarem Replies to Joseph Massad." Reset-DoC. Retrieved May 2, 2015, from http://www.resetdoc.org/story/00000001542

Puar, J. (2013). "I Would Rather be a Cyborg than a Goddess': Intersectionality, Assemblage, and Affective Politics." Meritum, revista de Direito da Universidade FUMEC, 8(2).

Puar, J. (2007). Terrorist Assemblages: Homonationalism in Queer Times. Duke University Press.

Said, E. (1978). Orientalism. New York: Vintage.

Taha, S. (April 21, 2013). Joseph Massad: an Occidentalist's Other Subjects/Victims. Retrieved May 2, 2015, from http://arableftist.blogspot.nl/2013/04/joseph-massad-occidentalists-other_21.html 
Kohl 1.1

169

Thiele, K. (2014). "Pushing Dualisms and Differences: From 'Equality versus Difference' to 'Nonmimetic Sharing and Staying With the Trouble." Women: A Cultural Review 25/1, 9-26. 